\title{
Cellulite in menopause
}

\author{
Marta Leszko \\ Department of Cosmetology, Regional Unit of Physical Education and Sport Department in Biała Podlaska, \\ Józef Piłsudski Physical Education Academy in Warsaw, Poland
}

\begin{abstract}
Menopause is a physiological process related to the increasing insufficiency of the hypothalamic-hypophyseal-ovarian axis. The pool of ovarian follicles capable of synthesizing female sex hormones becomes gradually depleted. In response to the sequence of endocrine changes of premenopause, perimenopause, and postmenopause, systemic somatic and emotional disturbances appear. Skin is the target organ for sex hormones. In women, the trophicity and appearance of the skin are most significantly affected by female sex hormones, estrogens and progesterone. However, this review also emphasizes the influences of other hormones on the skin and subcutaneous tissue.

During menopause, a low estrogen concentration is responsible for increased vascular permeability and decreased vascular tone, which lead to microcirculation impairment and are important factors predisposing to the development of cellulite. The effects of estrogen deficiency on the skin connective tissue include a decreased production and topical content of both type I and III collagen and elastin fibers, which also contributes to cellulite.

This paper presents diagnostic methods and clinical types of cellulite, as well as principal instrumental and manual treatments used for the reduction of the condition. Preparations containing ingredients which help to improve the metabolism of subcutaneous fat and enhance blood and lymphatic circulation, applied in cosmetology and esthetic medicine practice, have been reviewed. Furthermore, we provide an array of opinions regarding the effectiveness of treatment modalities presented here.
\end{abstract}

Key words: menopause, cellulite, hormones, microcirculation, oestrogen(s).

\section{Introduction}

The period of menopause is usually a long-standing running process with stormy hormone changes which are manifested with somatic systemic disorders and the lability of the emotional sphere. A pool of Graafian follicles, responsible for the production of female sex hormones, yields to the exhaustion. Hormone deficiencies can result in many dermatoses and may as well increase already existing manifestations. Frequently appearing skin defects are a consequence of these disorders, so are discolourations, hirsutism or cellulite. Correctly selected therapy is able to improve the appearance of the skin, and through that - increase the quality of life of menopausal women.

\section{Definition of cellulite}

The notion of cellulite was first defined by French doctors in 1922 [1]. From a medical point of view, these are fibrous and oedematous changes of the subcutaneous layer, lipodystrophy or oedemetical, fibrosing deviation of the connective tissue [2]. In this disease, because of disorders of the microcirculation, degenerative changes of the connective tissue occur. Cellulite is more and more often treated as illness, since as the definition of WHO demonstrates, it more and more often negatively influences a mental state of both women and men [3].

\section{Cellulite aetiology}

Hormonal imbalances are regarded as the crucial cause of the cellulite, and more precisely - too high concentration of oestrogens compared to the progesterone, that is relative hyperestrogenism [4]. Such a hormone situation can appear physiologically in the period of pregnancy, maturation, menopause, as well as while taking the systemic hormone contraceptive or in the course of the hormone replacement therapy. Development of cellulite is significantly influenced by two processes constantly occurring in fat cells - lipogenesis and lipolysis.

In the fatty tissue built from adipocytes, synthesis and disintegration occur. Lipogenesis is supporting the 
accretion of the fatty tissue, however lipolysis is a metabolic process which causes the decomposition of the stored-up fat. Exogenous and endogenic factors affect both processes. In the prevention of cellulite, it is important to keep balance between both processes. Local therapy is aimed at a change of the adipocyte metabolism and should limit lipogenesis and activate lipolysis.

Lipolysis is a process of destruction, disintegration and the reduction of lipids stored up in cells of the fatty tissue and muscle occurring with the participation of $\mathrm{li}$ pases. Endogenic factors regulating the lipolysis include such hormones and neurotransmitters as adrenaline and noradrenalin (demonstrating poorer action than adrenaline), estradiol and testosterone, adrenocorticotropic hormone $(\mathrm{ACTH})$, growth hormone $(\mathrm{GH})$, thyrotropin (TSH, thyroid stimulating hormone) and leptine, antidiuretic hormone and glucagon. Adrenaline being connected with receptors on the surface of $\beta 3$ adipocytes activates $G$ protein which excites adenyl cyclase and in the end increases cyclical AMP (cAMP). Protein kinase activated by CAMP stimulates the HSL (hormone-sensitive lipase) causing the disintegration of stored up lipids.

Neutral fat lipase (known as desnutrin) hydrolyzes triglycerides (TG) to diglycerides, and HSL decomposes diglycerides to monoglycerides [5]. Glycerol and free fatty acids are final products of the lipolysis (free fatty acids), being energy sources for cells.

Insulin which is suppressing the initiative of cyklase is the hormone blocking the process of lipolysis and it stimulates activity of lipoprotein lipase (LPL), responsible for the synthesis of lipids and the capture of free fatty acids. The process of lipogenesis is also dependent on SREBP-1 transcripting factor whose expression is increased by insulin. For this reason, a low concentration of this hormone can support the lipolysis process [6].

According to the theory of adipocytary receptors, $\alpha$ receptors intensify lipogenesis, however $\beta$ receptors support lipolysis. Adrenaline, belonging to catecholamines, comes mainly from adrenal medullae and fibres of the sympathetic nervous system, and the stimulation of fat cells is one of its roles with $\alpha$ - and $\beta$-adrenergic receptors. An influence on both kinds of receptors is an effect of its acting. The amount of $\beta$ adrenergic receptors is reduced under the influence of such factors as age - increasing the amount of the fatty tissue which extorts the response of $\alpha$ receptors. It can be the reason for the accumulation of fatty tissue in menopausal women. This relation causes the potential undesirable effect of anti-cellulite therapies [7].

Catechol amines speed up the process of the metabolism via $\beta$ receptors, affecting carbohydrates and fats economy [8]. The consequence of hypoestrogenism is the upset in the balance between noradrenalin, dopamine, serotonin or endorphins in the menopause. In- creased secretion of neuroendocrine can be a result of stress, affecting women in their menopause. Increasing the secretion of the noradrenalin shows the lack of the stability of the autonomous nervous system. In the period, the increased production of cortisol is connected with the climacteric and at the same time with a great concentration of adrenaline and noradrenalin [9].

Mostly oestrogens are the hormones responsible for the development of cellulite, as they are responsible for arranging the fatty tissue. In women, the production of the fatty tissue is independent of the amount of food eaten. The development of the fatty tissue is subject to an adjustment of local hormone mechanisms. Aromatase, which is elevated in the period of the menopause activity, modifies the deficiency of ovarian oestrogens [10], as well as it influences the lipid and glucose metabolism. This process causes the increase in adipocytes, which under the influence of the pressure on blood vessels and lymphatic vessels causes the growth of the local pressure, burdening, and also microcirculation. Shortage of the sex hormone in the menopause exerts an adverse influence on the vasculature [8]. It was proved that there is a close relationship between disorders of the venous circulation and pathological changes in the fatty tissue [3].

PPAR nuclear receptor affects the metabolism of the fatty tissue. Receptors are one of three kinds of PPAR gamma receptors which influence the maturing and diversifying of adipocytes. They stimulate the accumulation of lipids and increase the synthesis of adiponectin [6]. PPAR- $\alpha$ receptors are the second kind of units which influence $\beta$-oxidation of free fatty acids and serve as adjusters in lipogenesis [11]. Activated receptors through peroxisome proliferators of PPAR - retinal acid and conjugated linoleic acid (CLA) influence the lipolysis process [2]. Oestrogens activate the action of adrenergic receptors of the $\alpha$ type, and support the accumulation of fatty tissue in the region of thighs, hips and the pelvis, as well as influence the extension and increase the permeability of blood vessels. This results in the occurrence of microembolisms and microswellings. Oestrogens hinder the process of lipolysis and elevate lipogenesis. They influence the increased amount of glycosaminoglicans (Gag) which is contributing to impairment of the microcirculation (accumulating liquid in the intercellular space creates swelling which causes disorders in the microcirculation).

Progesterone has a relaxing effect on the fibres of smooth muscles and can cause the venostasis triggering disadvantageous morphological and functional changes [3]. Disorders in the microcirculation may cause a local rise in pressure and support the increased permeability of veins which is supplying the slow blood flow and increases the viscosity, creating the leukocytary trap. In individual periods of the menopause, an impact of subtle interactions on development of the 
cellulite is also being considered, namely the impact of oestrogens and other hormones, such as progesterone, growth hormone, melatonin, dehydroepiandrosteron, androgens or insulin which can additionally entail changes associated with the wrong transformation of fats and carbohydrates.

In the premenopause, in spite of lowering concentrations of the plasmatic estradiol, escalating luteal deficiency caused by more and more rare ovulations can translate into the state relative to hyperestrogenism, and this creates conditions for initiation of growth of the fatty cellulite along with the tendency of swellings.

Another issue is strongly expressed postmenopausal hypoestrogenism, as the maintained peripheral production of androgens, can cause relative hyperandrogenism in older women [12], which can influence the change of arranging of the fatty tissue which surrenders to reduction among others in places typical of women, and develops in the belly and torso regions as well as supports androidal (visceral) type of the build [13]. With age, reduced stimulation of oestrogens worsens the blood supply to the skin, suppresses the initiative of fibroblasts, disadvantages normal synthesis of collagen fibres and reduces the number of elastin fibres. Under the skin there can occur perceptible palpable irregularities - conglomerations of the bruised connective tissue underlined with the lack of the skin elasticity. Such changes are characteristic of the slender figure of the cellulite.

Amongst factors predisposing to the development of cellulite, rather than resulting directly from hormonal disorders, one should mention mostly the genetic factors. Family tendencies exist to wrong deposition of the fatty tissue and its characteristic organization at simultaneously underdeveloped muscle mass. Bad eating habits are other non-hormone risk factors for the development of cellulite. The increased supply of carbohydrates and fats supports hyperinsulinemia which, among others, intensifies the process of lipogenesis and is one of deciding aetiological factors. Badly balanced diet with a lot of preservatives and salt in the food supports retention of liquids which results in swellings.

Other factors are low physical activity and a sedentary lifestyle which disturb correct functioning of the microcirculation and support the accumulation of fatty tissue.

Nicotine and many other substances contained in the cigarette smoke cause constriction of blood vessels which supports tissue hypoxia. After certain time, loosened vessels and the improvement in oxidation conditions result in allowing reactive oxygen species to act in the process of hypoxia - the reoxygenation.

Dilators of the peripheral blood vessels applied in the arterial hypertension can affect the development of the cellulite: $\beta$-blocking agents, antihistamine and exogenous oestrogens [4].
Improperly selected clothes and footwear, especially wearing too close-fitting clothes, is definitely disturbing the venous outflow. Also high-heeled shoes, through the adverse impact on muscles of calves, disturb the good posture and weaken the function of the muscle pump of shins in transferring the venous blood to the heart.

In the prevention of cellulite, it is very important to pay attention to all factors predisposing to its formation. Some factors having a significant influence on cellulite, as for example genetic factors, are outside the range of any possible alteration, therefore it is worthwhile to concentrate on the elimination of factors, which we can have a real influence, like the change of the inappropriate diet or introducing a more active lifestyle.

\section{Clinical image of cellulite}

Clinically, nodular, uneven forming of the surface of the skin is a sign of cellulite. From a medical point of view, the structure of the tissue with cellulite differs from the fatty tissue above all with the increased number and the hypertrophy of adipocytes and with disturbed proportion between saturated and unsaturated fatty acids included in these cells, unfortunately to the advantage of saturated fatty acids [7].

Characteristic of both sexes, differences associated with the structure of the subcutaneous fatty tissue cause that lipodystrophy appears mainly in women, and in men exclusively in pathological states and while applying anti-androgen therapy (e.g. in the prostate cancer treatment). The cellulite in men is located within the neck and belly [7].

In women cellulite most often appears in regions of thighs, the belly and buttocks, in places, which have a lot of the receptors responsible for the lipogenesis [2].

So far no one has managed to prove the connection between cellulite and obesity, since cellulite also appears in slim and active persons.

It is possible to distinguish three main clinical types of the cellulite:

- fatty - by the overdeveloped fatty tissue;

- lymphatic - transitional, intensified mainly before the menstruation;

- alleged - appearing because of weakened tension of the gluteus muscle, visible on the back of thighs; it is possible to improve this state through the right exercises [14].

On account of character of skin changes it is possible to divide cellulite into:

- tough type (in women practising sports where the great cohesion of the skin and the well-developed musculature are characteristic);

- slender form (in women of the perimenopausal age, is also appearing after dieting; pliability of muscles is characteristic, the skin is poorly tense and loose); 
Tab. I. Photonumerical scale of cellulite intensification

\begin{tabular}{|c|c|}
\hline Clinical morphological features of cellulite advancement & Result \\
\hline \multirow[t]{4}{*}{ 1. Number of visible thickenings } & $0=$ absence of thickenings \\
\hline & $1=$ small number; $1-4$ visible thickenings \\
\hline & $2=$ average number; $5-9$ visible thickenings \\
\hline & $3=$ high number; 10 and more visible thickenings \\
\hline \multirow[t]{4}{*}{ 2. Depth of the thickenings } & $0-$ no changes \\
\hline & 1 - superficially deep changes \\
\hline & 2 - mild deep changes \\
\hline & 3 - deep changes \\
\hline \multirow[t]{4}{*}{ 3. Various morphological models of superficial models of skin changes } & $0-$ no affected areas \\
\hline & 1 - 'orange skin' look \\
\hline & 2 - 'cottage cheese' look \\
\hline & 3 - 'mattress' look \\
\hline \multirow[t]{4}{*}{ 4. Level of loosening and relaxation of the skin } & $0-$ absence of visible changes or skin creasings \\
\hline & 1 - light creasings \\
\hline & 2 - mild creasings \\
\hline & 3 - numerous creasings \\
\hline \multirow{4}{*}{$\begin{array}{l}\text { 5. Nürnberger and Müller's classification scale - in the standing position } \\
\text { subjected to 'pinching test' (at the relaxed buttock muscle there may } \\
\text { not be visible creases; this allows to differentiate } 0 \text { from } 1 \text { ) }\end{array}$} & 0 -zero degree \\
\hline & 1 - first degree \\
\hline & 2 - second degree \\
\hline & 3 - third degree \\
\hline
\end{tabular}

- hydropic form (the most severe form, appears in women with serious disorders of the cardiovascular system) [2].

\section{Cellulite diagnosis}

Cellulite is diagnosed by a cosmetologist or a dermatologist. A palpable medical examination and a visual evaluation are the basis of assessment of cellulite. There are many scales of the evaluation of cellulite (Table I). A scale that is universally used is NürnbergerMüller's scale. The scale of 2009 - Doris Maria Hexsel's photonumerical scale of cellulite intensification - is newer and regarded more exact (Table II). Based on photographs of 55 patients with cellulite, five key aspects were distinguished in the assessment of this problem.

A new classification mentions three stages of cellulite advancement:

A photonumeric scale of intensifying changes in cellulite is extremely valuable in monitoring therapeutic anti-cellulite methods and can be applied for examining affected patients [15].

It is also possible to assess cellulite basing on specialist examinations: thermography (it determines the temperature of the surface of the body, and colours are indicating the temperature of the tissue), macrography, TEWL determination (measurement of transcutaneous dehydration), the apparatus measurement of greasing or the skin elasticity, videocapillaroscopy (the examina- tion assesses the state of the filling of capillaries: in the place of the advanced cellulite the tissue is poorly supplied with blood), electric bioimpedance (determines content of the fatty tissue and water in the body). However in the diagnosis of cellulite, computed axial tomography, magnetic resonance and ultrasonography turned out to be extremely useful.

But neither the computed axial tomography nor the magnetic resonance can be universally used on account of their costs and in the case of the computed axial tomography as for the radiation exposure to X-ray. Therefore, ultrasonography is more and more general and objective than the palpable scale. The research on the evaluation of cellulite is performed basing on classical ultrasound scanners and of high frequencies.

Classical ultrasonography assesses such parameters as fatness of the corium and, of the subcutaneous layer, echogenicity of both structures, and the border between the corium and subcutaneous layer [16]. In the high frequency ultrasonography it is possible to assess the

Tab. II. Structure of cellulite intensification scale and its new typology

\begin{tabular}{lc}
\hline Cellulite intensification scale & New typology \\
\hline $1-5$ & Mild form \\
\hline $6-10$ & Average form \\
\hline $11-15$ & Advanced form \\
\hline
\end{tabular}


following parameters: the fatness of the cuticle and corium, presence of swellings, echogenicity of corium and what is most essential, the advanced process of forming the root of the corium in the subcutaneous layer [17].

\section{Methods of cellulite treatment}

Treatments aimed at reduction of cellulite should be conducted comprehensively and should have a multidirectional action. One should be aware that they will not eliminate the problem, and they will only slightly reduce its area and therefore will affect the temporary improvement in the appearance of the skin. Nevertheless, this result can be essential for menopausal women.

Methods reducing cellulite are cosmetic procedures, cosmetic surgery, pharmacology, and surgeon's proceedings.

The basis of home therapy is:

1. Application of cosmeceutics, containing active ingredients:

- Improving the tightness of blood and lymphatic vessels, e.g. flavonoids, antioxidants, saponins, tannins, which also help eliminate unnecessary products of metabolism. The above-mentioned group of substances appear in extracts from arnica, and seeds and leaves of the horse chestnut.

- Intake of compounds of plant origin increases the process of lipolysis, but suppresses lipogenesis such as caffeine, extracts from guarana, Garcinia gummigutta, theophylline, xanthine (come from coffee, the green tea and the Paraguayan tea).

- Toning and moistening substances applied in anticellulite cosmetology: hyaluronic acid, vitamin A and E, urea, plant extracts, amino acids and hydroxyacids.

2. Supplementation - is based above all on products containing caffeine and vitamin $\mathrm{B}_{1 \mathrm{~s}}, \mathrm{~B}_{5}, \mathrm{~B}_{9}$ and $\mathrm{B}_{12}$.

- Physical activity, sport, appropriate diet. A preventive program containing information about factors affecting the development of cellulite and methods of its elimination. The basis of precaution and also of elimination of risk factors is:

- preventing the development of the advanced stage of the cellulite, most resistant to therapy. It is also important to make women aware of the need of periodic medical check-ups.

The most popular treatments in the cosmetic and cosmetic surgery areas applied to reduce the cellulite are:

- Lymphatic drainage - works positively on lymphatic vessels, eliminates swellings, is also beneficial for deep layers of the skin.

- Endermology - apparatus massage; increases oxidation of tissues, improves skin elasticity, hastens the apoptosis of fat cells, however does not strengthen the corium [18-20].

- Velasmooth ${ }^{\mathrm{TM}}$ is at present the most effective appliance in the treatment of cellulite in a non-invasive method, in which three energy sources are used: infrared, bipolar electricity of high frequency (RF), the impulse suction and massage. Their cooperation considerably increases the effect in comparison to results obtained when using single energy sources. All three energies are being administered to the tissue simultaneously, using one therapeutic head. The treatment comprises 10-12 sessions which are taken twice a week for 5-6 weeks [20].

- Triactive ${ }^{\mathrm{TM}}$ - three various methods are being used for the treatment: the diode laser, cryotherapy, deep massage and lymphatic drainage. The diode laser stimulates the reconstruction of vessels in the subcutaneous layer, cryotherapy reduces swelling and lymphatic drainage and massage stimulate blocked circulation of lymph expelling water and unnecessary products of metabolism from the organism. Series are usually applied in about 10-15 treatments 1-2 times a week [20].

- SmoothShapes ${ }^{\mathrm{TM}}$ - the device is using three technologies - connecting the laser, biostimulating light, massage with rolls and vacuum [20].

- Alma Accent ${ }^{\mathrm{TM}}$ RF system - the device is a source of high frequency waves for collagen remodelling, improving texture of the skin and cellulite reduction. It uses two types of radio frequency: unipolar and bipolar. By proper applying different heads for heating (of heat treatment), appropriate layers of the skin and the subcutaneous layer are treated.

- IR rays - trigger thermogenesis after which the reduction in fat cells takes place.

The techniques of the cellulite reduction include strictly medical aesthetic treatments:

- Liposuction - during the treatment a local excess of fat is removed - operation performed by surgeons. Liposuction can be made with the help of lasers and apparatuses producing airwaves. In medicine, applying high frequency waves causes effects of the overheating of tissues. Modern apparatuses are equipped with the cooling system that prevents burns of the skin (cryogenic liquid) and exchangeable treatment heads. The treatment consists in the proper dosage of airwaves, of which the energy is turned into the central heating, stimulating cells to produce collagen; waves work on the corium and the subcutaneous layer. The treatment improves firmness and density of the skin [20].

- Mesotherapy - method consisting in applying subcutaneous injections with nutrients and healing agents (silica, caffeine, tiratricol). It assists the lipolysis which reduces cellulite, but it does not directly affect the fat tissue causing cellulite.

- Injection lipolysis - lipolysis can be applied to supplement liposuction, but cannot replace it; the treatment consists in the reduction in the local fatty tissue with the injection; phosphatidylcholine has most of- 
ten been applied and sodium deoxycholate, but both are registered for this purpose. At present for the injection lipolysis surgery, one uses a new injection technique - intralipotherapy - which was registered in 2007 and popularised by Professor Motolese as Aqualyx preparation. Gel is also applicable in the "noneedle' mesotherapy against defluvium - Dermaheal HR. Professor Maurizio Ceccarelli is using vitamin C and iron for the lipolysis which causes the apoptosis of fat cells.

- Cryolipolysis consists in exploiting cryotherapy and is applied for the reduction of the fatty tissue. Under the influence of the low temperature, cell membranes of adipocytes are yielding to injury. Next, lipids undergo crystallization, what in the end leads to their apoptosis. Lipids from adipocytes are consumed by macrophages. During one treatment not always we can destroy all cells - treatment performed by dermatologists and surgeons [14].

Same as all medical treatments, anti-cellulite treatments should always be preceded by a thorough interview and medical consultation. When choosing treatment, especially for menopausal women, one should take the current medical condition into account, because diseases coexisting in this period can often make the treatment impossible. The contraindication for intensive manual and apparatuses treatments is diseases already frequent in this lifespan, including arterial hypertension, osteoporosis, type 2 diabetes and the venous failure.

Pharmacological therapy is considerably popular for improving the appearance of the skin with the cellulite. In women applying hormone replacement therapy (HRT), by no means, quality and an amount of the accepted gestagenic component, or the route of administration, should be considered as marginal. In oral administration, mineral corticosteroid activity of gestagen can stimulate the system: renin-angiotensinaldosterone which stops water and electrolytes in the system. Activity of glycocorticoid may cause contraction of blood vessels, dismissal of the blood flow and venostasis, as well as blood coagulability among others [17]. Androgenic activity of gestagen entails negative changes in the profile of lipids of blood, increasing local atherosclerotic processes [21].

In other words, disorders of the microcirculation are common characteristics of adverse reactions of the gestagenic hormone replacement therapy, one of important factors in the aetiology of cellulite. The percutaneous hormone treatment reduces the above side effects. In pharmacological therapy of the cellulite, medicines streamlining and normalizing the metabolism of the fatty tissue are also applicable. Methyloxantines stimulate lipolysis. Pentoxifylline corrects the microcirculation and is advantageous for the immunological system [1].
Good effects are obtained by combined therapy. These are most often treatments from the cosmetic area, connected with applying cosmeceutics, with an increased physical activity and appropriate diet. Even though they will not get rid of the cellulite permanently, they will improve the general state of the skin, and hence improve self-assessment of women in the period of the menopause.

\section{Conclusions}

Cellulite is a clinical state stirring up a lot of controversy. There is explicitly no effective method of getting rid of this disease [22]. From the point of view of physiology, preparations recommended by producers as those getting rid of cellulite demonstrate limited efficacy. By definition, cosmetic substances crossing border layers of the cuticle do not demonstrate the effective action towards changed tissues. Cosmetic substances a priori cannot reach changed tissues.

Only products including in their composition accelerators of percutaneous passage, such as ethanol, isopropanol, propylene glycol or $\alpha$-hydroxyacids can facilitate transport of active ingredients which can affect the metabolism of the fatty tissue. Assuming that cellulite is a state resulting from changes of the structure of the fatty tissue, it is understandable that the motor activity cannot be an effective method in itself of getting rid of the cellulite. This problem affects both slim and obese women.

Regularly applied treatments made with the help of apparatus, provide satisfactory, but short-lived, effects. Amongst methods listed in the article, a beneficial effect of massage should be mentioned, and more precisely the fact that exerted pressure on adipocytes blocks their diversification, which makes the accumulation of fatty tissue impossible [23]. Gentle massage with elements of aromatherapy is peculiarly recommended for women in the menopausal period, since added oils not only work favourably on the state of the skin, but also improve the psychological condition.

One should nurse a hope that research works of the nearest years will verify the effectiveness of new therapies and will allow us to gain more information about the cellulite.

\section{Disclosure}

Author reports no conflict of interest.

\section{References}

1. Haneke E. Cellulit - fakty i mity. Dermatologia Estetyczna 2006; 3: 132138.

2. Ciupińska M, Noszczyk M. Pielęgnacja ciała. Częste problemy estetyczne i zdrowotne sylwetki i skóry ciała. Kosmetologia pielęgnacyjna i lekarska. Wydawnictwo Lekarskie PZWL, Warszawa 2010; 189-209.

3. Pura-Rynasiewicz A. Cellulit - choroba czy defekt kosmetyczny? Dermatologia i Uroda 2010; Wiosna-Lato: 3-4. 
4. Woźniak M, Zegarska B, Kaczmarek-Skamira E. Cellulit (III). Patogeneza. Dermatologia Estetyczna 2011; 3: 149-150.

5. Wolf $\mathrm{G}$. The mechanism and regulation of fat mobilization from adipose tissue: desnutrin, a newly discovered lipolytic enzyme. Nutr Rev 2005; 63: 166-170.

6. Siemińska L. Endokrynologia Polska. Polish Journal of Endocrinology 2007; 58: 330-347.

7. Martini MC. Kosmetologia i farmakologia skóry. Wydawnictwo Lekarskie PZWL, Warszawa 2007; 300-309.

8. Skatba P. Receptory, hormony ptciowe, leki stosowane w hormonalnej terapii. W: Skałba P (ed.). Hormonalna terapia zastępcza. Wyd. II. Wydawnictwo Lekarskie PZWL, Warszawa 2005; 88-50.

9. Sobstyl M, Bednarek W, Tkaczuk-Włach J, et al. Objawy naczynioruchowe w menopauzie - diagnostyka i leczenie. Prz Menopauzalny 2011; 3: 254-259.

10. Wojnowska D, Juszkiewicz-Borowiec M, Chodorowska G. Wpływ menopauzy na starzenie się skóry. Post Dermatol Alergol 2006; 3: 149-156.

11. Warenik-Szymankiewicz A, Halerz-Nowakowska B. Diagnostyka w endokrynologii ginekologicznej. W: Pawlikowski M (ed.). Zaburzenia hormonalne. Wydawnictwo Lekarskie PZWL, Warszawa 2003; 251-257.

12. Pertyński T, Stachowiak G, Stetkiewicz T. Rola ginekologa w okresie prei okołomenopauzalnym. Prz Menopauzalny 2007; 2: 251-254.

13. Kos-Kudła B, Staszewicz P. Otyłość u kobiet w okresie około- i pomenopauzalnym. W: Skałba P (ed.). Hormonalna terapia zastępcza. Wyd. II. Wydawnictwo Lekarskie PZWL, Warszawa 2005; 316-333.
14. Załęska-Żyłka I. Cellulit jako problem medyczny. Problemy Higieny i Epidemiologii 2008; 89: 487-491.

15. Hexsel D, Dal'Forno T, Hexsel C. A validated photonumeric cellulite severity scale. J Eur Acad Dermatol Venereol 2009; 23: 523-528.

16. Mlosek RK. Ultrasonograficzne badanie skóry. Ultrasonografia 2011; 47: 58-62.

17. Mlosek R, Dębowska R, Lewandowski $M$, et al. Zastosowanie badań ultrasonograficznych wysokiej częstotliwości w monitorowaniu terapii antycellulitowej - doświadczenia własne. Polish Journal of Cosmetology 2008; 11: 283-294.

18. Miękoś-Zydek B, Czyż P, Ograczyk A. Mezoterapia w dermatologii i dermatologii estetycznej. W: Adamski Z, Kaszuba A (eds.). Dermatologia dla kosmetologów. Elsevier Urban \& Partner, Wrocław 2010; 281-285.

19. Wilk M, Dankowska S, Adamski Z. Gabinet kosmetyczny. W: Adamski Z, Kaszuba A. Dermatologia dla kosmetologów. Elsevier Urban \& Partner, Wrocław 2010; 424-429.

20. Wassef C, Rao Babar K. The science of cellulite treatment and its longterm effectiveness. J Cosmet Laser Ther 2012; 14: 50-58.

21. Stachowiak G, Stetkiewicz T. Choroba zakrzepowo-zatorowa w okresie menopauzalnym. Prz Menopauzalny 2010; 4: 212-216.

22. Avram MM. Cellulite: a review of its physiology and treatment. Journal of Cosmetics and Laser Therapy 2004; 6: 181-185.

23. Kasprzak W, Mańkowska A. Fizykoterapia, medycyna uzdrowiskowa i SPA. Wydawnictwo Lekarskie PZWL, Warszawa 2008; 332-339. 